\title{
Sonnet-Première Etude
}

L'avril frais de ma vie s'enfult devant mes yeux. Que deviens-tu, 0 Temps de ma verte innocence, Quand Katmandu, dada vivant, fut ma croyance Unique dans ce monde bref de ciel si bleu?

Pareil à Emile, je découvris deux par deux Tous les éléments sans jamais toucher Térence. Mon cabinet étala une grande affluence De trésors naturels avant 1 'entrée du feu.

Le Moi hivernal répand sa noire tristesse. La gaieté d'antan se meurt devant la vieillesse. Plongé dans cet univers glacial de frimas,

Je me détruis peu à peu. Quand s'éteint mon cierge? Le désespoir me tient dans ses atroces bras. Eternelle femme, quels ravages d'un coeur vierge!

JOSEPH GEORGE REISH WESTERN MICHIGAN UNIVERSITY 


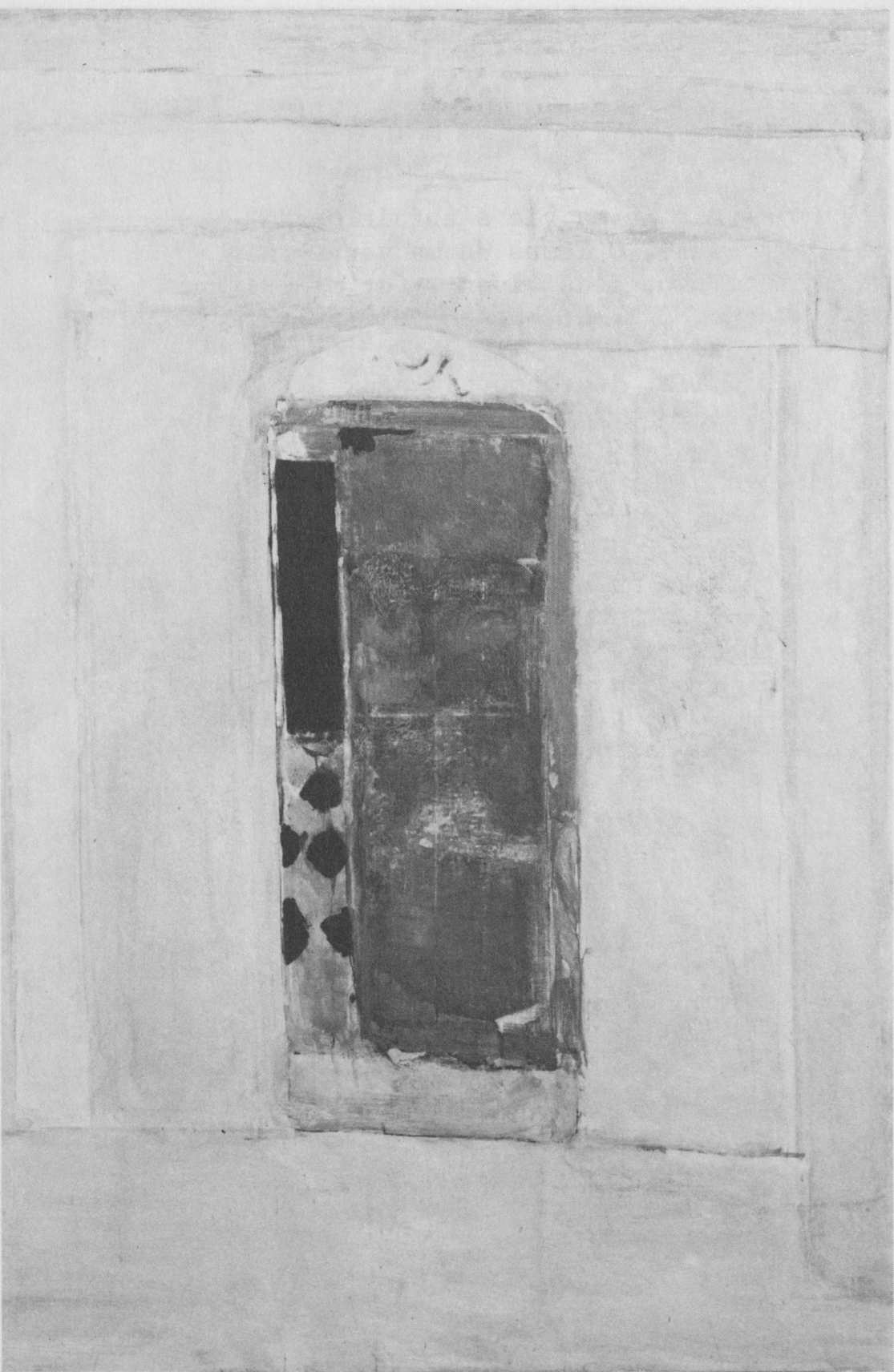

